\title{
UJI AKTIVITAS ENZIM SELULASE ISOLAT BAKTERI DARI SEDIMEN LAMUN PERAIRAN RENDANI MANOKWARI
}

\author{
The Test of Cellulase Enzyme Activity of Isolate Cellulolytic Bacteria \\ from Seagrass Sediment, Rendani Manokwari \\ Tirzah E. Bandi, Hermawaty Abubakar, Rina A. Mogea* \\ Program Studi Biologi, Fakultas Matematika dan Ilmu Pengetahuan Alam Universitas Papua \\ Manokwari, Manokwari 98314, Indonesia
}

*Korespondensi: rinamogea@gmail.com

\begin{abstract}
Indonesia has the potential of renewable natural resource which are abundant both in number and types of plants containing cellulose fiber. In natures cellulose cannot be completely degraded because it needs of microorganisms such as fungi and bacteria which will produce cellulase enzymes so that it can degrade cellulose in nature. The purpose of this study was to analysed the activity of cellulase enzymes produced by bacterial isolates obtained from seagrass sediments. Cellulase activity of 11 bacterial isolates was determined by the cellulotic index value passing through the Congo Red staining method on $1 \% \mathrm{CMC}$ solid media. A total of seven isolates indicated a positive result and the highest index value was produced by SI-E isolates, that is $4.7 \mathrm{~mm}$. After that the value of cellulase enzyme activity from the seven positive isolates was determined by counting substrate reducing sugars through the 3.5-dinitrosalicylic (DNS) method. The results showed that SI-H isolates had the highest activity of $0.071 \mathrm{U} / \mathrm{mL}$.
\end{abstract}

\begin{abstract}
ABSTRAK
Indonesia memiliki potensi berupa sumber daya alam terbaharukan yang melimpah baik dalam jumlah maupun jenis tumbuhan yang mengandung serat selulosa. Di alam selulosa tidak dapat terdegradasi secara sempurna oleh karena itu dibutuhkan bantuan mikroorganime seperti jamur dan bakteri yang akan menghasilkan enzim selulase sehingga dapat mendegradasi selulosa yang berada di alam. Tujuan dari penelitian ini adalah untuk menganalisis aktivitas enzim selulase yang dihasilkan oleh isolat bakteri yang digunakan. Aktivitas selulase dari 11 isolat bakteri ditentukan dengan nilai indeks selulotik melaluli metode pewarnaan merah kongo pada media padat CMC $1 \%$. Sebanyak tujuh isolat yang menandakan hasil positif dan nilai indeks tertinggi dihasilkan oleh isolat SI-E yaitu $4.7 \mathrm{~mm}$. Setelah itu nilai aktivitas enzim selulase dari ketujuh isolat positif ditentukan dengan menghitung gula pereduksi substrat melalui metode 3.5-dinitrosalisilat (DNS). Hasil menunjukkan isolat SI-H memiliki aktivitas tertinggi yaitu $0.071 \mathrm{U} / \mathrm{mL}$.
\end{abstract}

Keywords: Cellulase, Enzyme, Bacteria, Sedimen, Lamun

\section{PENDAHULUAN}

Selulosa dapat dihidrolisis secara enzimatis oleh enzim selulase yang dihasilkan oleh jenis mikroorganisme yang memiliki kemampuan untuk mendegradasi substrat yang

mengandung selulosa. Enzim selulase adalah enzim ekstraseluler yang dihasilkan di dalam sel kemudian dikeluarkan ke medium pertumbuhan nya. Enzim ini sangat penting dalam proses 
biokonversi (perubahan secara biologi) limbahlimbah organik berselulosa menjadi glukosa. Enzim selulase ini dapat dihasilkan oleh bakteri selulotik karena kemampuannya mendegradasi selulosa yang terdapat dalam media pertumbuhannya. Beberapa spesies bakteri seperti genus Acetobacter, Bacillus, Cellulomonas, Cythopaga, Sarcina, dan Vibrio diketahui mampu menghasilkan enzim selulase (Mosier et al., 2005).

Dunia industri menggunakan enzim selulosa untuk berbagai keperluan sebab biaya produksi tidak mahal dan waktu produksi singkat. Selulase digunakan dalam industri tekstil yaitu mencegah penumpukan noda, mengembalikan warna, menghaluskan permukaan dan menghilang noda tanah pada kain, industri makanan yaitu untuk melembutkan sayuran, mengeluarkan kulit biji-bijan, mengeluarkan agar-agar dari rumput laut. Selulase banyak digunakan dalam industri pulp dan kertas untuk modifikasi serat, pengelolaan limbah, industri farmasi, dan juga digunakan dalam industri bioethanol.

Meningkatnya pertumbuhan sektor perkebunan, kehutanan, pertambangan di Papua Barat menyebabkan banyaknya limbah yang dibuang ke lingkungan perairan dan limbah yang dihasilkan mengandung polimer karbohidrat. Polimer ini dimanfaatkan oleh mikroorganisme sebagai sumber karbon untuk pertumbuhannya dengan cara memproduksi enzim. Limbah karbohidrat yang stabil di perairan adalah selulosa dan untuk mendegradasinya diperlukan bakteri yang bersifat selulotik. Penelitian yang dilakukan Hamel (2015) memperoleh 11 isolat bakteri dari sedimen Lamun dari Pantai Rendani Manokwari yang mampu menghasilkan enzim selulase secara kualitatif. Penelitian ini bertujuan untuk menganalisis aktivitas enzim selulase secara kualitatif dari 11 isolat yang diperoleh dari penelitian Hamel.

\section{METODE}

\section{Peremajaan Isolat Bakteri}

Isolat bakteri koleksi Laboratorium Mikrobiologi FMIPA UNIPA sebanyak 11 isolat dengan kode SI diinokulasikan pada media miring NA, dan diinkubasi pada suhu $27^{\circ} \mathrm{C}$ selama \pm 24 jam. Jika sudah murni dan tidak terkontaminasi maka isolat tersebut akan digores pada media NA di petridish untuk digunakan pada tahap uji kualitatif bakteri selulotik.

\section{Uji Kualitatif Bakteri Selulotik (Modifikasi Metode Meryandini et al., 2009)}

Uji kualitatif menggunakan metode Meryandini el al., (2009) yang dimodifikasi yaitu dengan cara melihat adanya zona bening pada media padat selektif CMC $1 \%$ dalam $500 \mathrm{~mL}$ mengandung $\mathrm{NH}_{4} .2 \mathrm{SO}_{4} 0.5 \mathrm{~g} ; \mathrm{MgSO}_{4} .7 \mathrm{H}_{2} \mathrm{O} 0.5 \mathrm{~g}$; $\mathrm{MnSO} 40.5 \mathrm{~g}$; Yeast extract $0.5 \mathrm{~g} ; \mathrm{FeCl}_{3} .7 \mathrm{H}_{2} \mathrm{O}$ $0.5 \mathrm{~g}$; CMC 5g; Agar 11g. Diinkubasi pada suhu $27^{\circ} \mathrm{C}$ selama \pm 24 jam. Uji kualitatif bakteri yaitu isolat murni yang tumbuh pada media NA, diinokulasikan pada media padat selektif CMC $1 \%$ dan diinkubasi pada suhu $27^{\circ}$ selama 3 hari. Isolat yang terlihat atau tumbuh pada media selektif kemudian ditambahkan 3-4 tetes reagen congo red dan di spreader secara merata ke seluruh media selektif dan dibiarkan selama 30 menit. Setelah 30 menit, dilakukan pengamatan untuk melihat terbentuknya zona bening pada media selektif CMC $1 \%$ serta mengukur besar zona tersebut. Aktivitas selulotik dapat ditentukan dengan nilai indeks selulotik. Indeks selulotik merupakan nisbah antara diameter zona bening dengan diameter koloni (Zahidah et al., 2013).

Keterangan:

$$
\mathrm{IS}=\frac{\mathrm{X} 1-\mathrm{X} 2}{\mathrm{X} 2}
$$

$$
\begin{array}{ll}
\mathrm{IS} & =\text { Indeks Seluiotı } \\
\mathrm{X} 1 & =\text { Rata-rata diameter zona bening } \\
\mathrm{X} 2 & \text { Rata-rata diameter koloni }
\end{array}
$$

\section{Produksi Enzim Selulase}

Enzim diproduksi dengan dikultur pada media NB yang digunakan sebagai media produksi enzim selulase. Produksi enzim selulase yaitu dibuat media NB, kemudian inokulasikan inokulum isolat bakteri SI ke media cair produksi enzim selulase. Kultur cair tersebut dishaker dengan kecepatan agitasi $115 \mathrm{rpm}$ pada suhu $37^{\circ} \mathrm{C}$ selama \pm 24 jam. Setiap kultur yang mengandung enzim dipisahkan dari bakteri menggunakan centrifuge berkecepatan $9000 \mathrm{rpm}$ selama 10 menit. Supernatan yang diperoleh akan digunakan pada tahap selanjutnya yaitu tahap 
pengujian aktivitas enzim selulase secara kuantitatif.

\section{Aktivitas Enzim Selulase}

Uji aktivitas enzim selulase ekstraseluler dilakukan dengan cara menghitung jumlah kadar glukosa dari hasil hidrolisis selulosa menggunakan enzim selulase dengan metode DNS. Tabung untuk sampel diisi dengan $1.75 \mathrm{~mL}$ ekstrak enzim kemudian ditambahkan $1 \mathrm{~mL}$ larutan CMC Broth 1\% dan divortex. Kemudian tabung sampel tersebut diinkubasi selama 15 menit dalam waterbath suhu $55^{\circ} \mathrm{C}$. Tambahkan $1.5 \mathrm{~mL}$ reagen DNS pada tabung sampel dan didihkan lagi selama 15 menit dalam waterbath . Setelah itu tabung sampel akan dikeluarkan dari dalam waterbath untuk didinginkan. Sedangkan untuk tabung kontrol berisi $1.75 \mathrm{~mL}$ ekstrak enzim ditambah $1 \mathrm{~mL}$ CMC broth $1 \%$ dan $1.5 \mathrm{~mL}$ reagen DNS namun tidak diinkubasi dalam waterbath Untuk tabung blanko berisi $1 \mathrm{~mL}$ CMC broth $1 \%$ dan $1.5 \mathrm{~mL}$ DNS dan tidak diinkubasi. Absorbansi masing-masing larutan diukur dengan spektrofotometer UV-VIS pada panjang gelombang $540 \mathrm{~nm}$. Nilai aktivitas selulase ditentukan berdasarkan perhitungan sebagai berikut:

$$
\begin{aligned}
& \begin{array}{l}
\text { Aktivitas } \\
\text { selulase } \\
(\mathrm{U} / \mathrm{mL})
\end{array} \\
& \text { BM glukosa } x \text { Waktu inkubasi }
\end{aligned}
$$

\section{Analisis Data}

Hasil pengamatan di Laboratorium dianalisis secara kualitatif dan kuantitatif yang disajikan dalam bentuk gambar dan tabel. Analisis secara kualitatif meliputi terbentuknya zona bening dan perubahan warna pada media sedangkan secara kuantitatif meliputi indeks selulotik dan nilai aktivitas enzim selulase.

\section{HASIL DAN PEMBAHASAN}

Isolat bakteri murni yang diinokulasikan pada media selektif CMC $1 \%$ untuk mendeteksi bakteri yang dapat menghasilkan enzim selulase dengan membentuk zona bening disekitar koloni bakteri setelah ditetesi reagen congo red.

Kemampuan bakteri dalam menghasilkan enzim selulase ditunjukkan dalam Gambar 1 . Dari 11 isolat bakteri yang diinokulasikan pada media selektif CMC $1 \%$ hanya tujuh isolat yang mampu menghasilkan enzim selulase dengan membentuk zona bening pada media (Tabel 1). Ke-tujuh isolat yang menunjukkan adanya aktivitas enzim selulase kemudian dilanjutkan ke tahap selanjutnya yaitu perhitungan indeks selulotik untuk mengetahui besar dan kecilnya zona yang terbentuk pada media selektif CMC $1 \%$.

Tabel 1. Isolat Bakteri Penghasil Enzim Selulase

\begin{tabular}{cccc}
\hline & Kode & \multicolumn{2}{c}{$\begin{array}{c}\text { Hasil Uji } \\
\text { Nktivitas Enzim }\end{array}$} \\
\cline { 3 - 4 } & Isolat & Positif & Negatif \\
\hline 1 & SI -C & $\sqrt{ }$ & $\sqrt{ }$ \\
2 & SI - D & & \\
3 & SI - E & $\sqrt{ }$ & \\
4 & SI - F & $\sqrt{ }$ & \\
5 & SI - H & $\sqrt{ }$ & \\
6 & SI - J & & $\sqrt{ }$ \\
7 & SI - L & $\sqrt{ }$ & $\sqrt{ }$ \\
8 & SI - M & & \\
9 & SI - O & & \\
10 & SI - P & $\sqrt{ }$ \\
11 & SIII -C & $\sqrt{ }$ \\
\hline
\end{tabular}

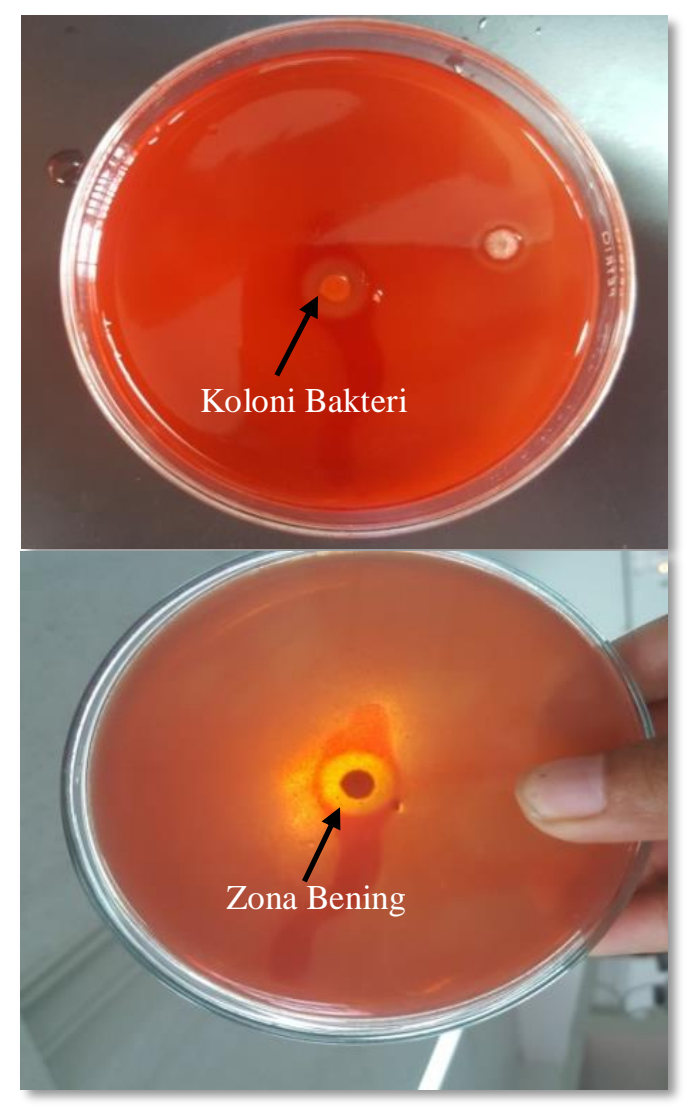

Gambar 1. Aktivitas enzim selulase secara kualitatif 
Pengukuran diameter zona bening pada tujuh isolate yang menunjukkan hasil positif bertujuan untuk menentukan berapa besar zona bening yang dibentuk oleh bakteri tersebut. Hasil pengukuran menunjukkan adanya perbedaan ukuran zona bening dan ukuran koloni yang terbentuk antara isolat yang satu dengan isolat yang lainnya (Tabel 2).

Tabel 2. Indeks Aktivitas Selulotik

\begin{tabular}{ccccc}
\hline No. & $\begin{array}{c}\text { Kode } \\
\text { Isolat }\end{array}$ & $\begin{array}{c}\text { Ukuran } \\
\text { Zona } \\
\text { Bening } \\
(\mathrm{cm})\end{array}$ & $\begin{array}{c}\text { Ukuran } \\
\text { Koloni } \\
(\mathrm{cm})\end{array}$ & $\begin{array}{c}\text { Indeks } \\
\text { Selulotik } \\
(\mathrm{mm})\end{array}$ \\
\hline $\mathbf{1}$ & SI-C & 1.8 & 0.6 & 2 \\
$\mathbf{2}$ & SI-E & 1.7 & 0.3 & 4.7 \\
$\mathbf{3}$ & SI-F & 1.5 & 0.7 & 1.1 \\
$\mathbf{4}$ & SI-H & 2 & 0.6 & 2.3 \\
$\mathbf{5}$ & SI-L & 1.5 & 0.5 & 2 \\
$\mathbf{6}$ & SI-P & 1.3 & 0.4 & 2.2 \\
$\mathbf{7}$ & SIII-C & 2 & 0.5 & 3 \\
\hline
\end{tabular}

Tujuh isolat yang berhasil menghasilkan enzim selulase secara kualitatif kemudian akan diuji secara kuantitatif. Uji kuantitatif dilakukan dengan mengetahui aktivitas selulase yang diukur berdasarkan jumlah gula pereduksi menggunakan metode asam dinitrosalisilat (DNS). Berdasarkan hasil uji kuantitatif tujuh isolat bakteri yang diuji memiliki nilai aktivitas enzim yang bervariasi (Tabel 3), dimana isolat bakteri SI-H yang memiliki nilai aktivitas tertinggi yaitu 0.071 $\mathrm{U} / \mathrm{mL}$ dan nilai aktivitas terendah dimiliki oleh isolat bakteri SI-E yaitu $0.004 \mathrm{U} / \mathrm{mL}$.

Tabel 3. Aktivitas Enzim Selulase

\begin{tabular}{|c|c|c|c|c|}
\hline \multirow[t]{2}{*}{ No. } & \multirow[t]{2}{*}{$\begin{array}{l}\text { Kode } \\
\text { Isolat }\end{array}$} & \multirow{2}{*}{$\begin{array}{l}\text { Aktivitas } \\
\text { Enzim } \\
\text { Selulase } \\
\text { (U/mL) }\end{array}$} & \multicolumn{2}{|c|}{$\begin{array}{c}\text { Golongan } \\
\text { Bakteri }\end{array}$} \\
\hline & & & $\begin{array}{c}\text { Gram } \\
-\end{array}$ & $\begin{array}{c}\text { Gram } \\
+\end{array}$ \\
\hline 1. & $\mathrm{SI}-\mathrm{C}$ & 0.042 & $\sqrt{ }$ & \\
\hline 2. & $S I-E$ & 0,004 & $\sqrt{ }$ & \\
\hline 3. & $S I-F$ & 0,016 & & $\sqrt{ }$ \\
\hline 4. & $\mathrm{SI}-\mathrm{H}$ & 0,071 & $\sqrt{ }$ & \\
\hline 5. & $\mathrm{SI}-\mathrm{L}$ & 0,014 & $\sqrt{ }$ & \\
\hline 6. & $\mathrm{SI}-\mathrm{P}$ & 0,008 & $\sqrt{ }$ & \\
\hline 7. & SIII - C & 0.039 & $\sqrt{ }$ & \\
\hline
\end{tabular}

Keterangan: Golongan bakteri dari tujuh isolat bersumber dari penelitian Hamel (2016)

Seleksi mikroba selulotik secara kualitatif bertujuan untuk mengetahui ada atau tidaknya aktivitas enzim selulotik dari suatu isolat. Salah satu uji kualitatif yang umum digunakan yaitu pewarnaan dengan larutan merah kongo atau yang biasa dikenal dengan sebutan congo red. Uji ini dilakukan dengan menumbuhkan isolat bakteri pada media agar yang mengandung karboksilmetil selulosa (CMC) dan diinkubasi pada suhu ruang $\left(27^{\circ} \mathrm{C}\right)$. Karboksilmetil selulosa (CMC) merupakan suatu polimer anionik yang umum digunakan pada pengujian aktivitas selulase (Lee, 2008). CMC merupakan polimer dengan bobot molekul tinggi sehingga tidak dapat ditranspor ke dalam sel mikroorganisme (Kim et al., 2004). Enzim selulase merupakan senyawa metabolit sekunder yang bersifat ekstraseluler (Imas, 2009). Hal ini menyebabkan enzim tersebut akan disekresikan dalam media tumbuh isolat tersebut.

Isolat bakteri dengan kode SI yang berjumlah 11 isolat ditumbuhkan pada media agar CMC 1\% dan diinkubasi selama tiga hari pada suhu ruang $\left(27^{\circ} \mathrm{C}\right)$. Zona bening akan terlihat ketika pewarna merah kongo atau congo red ditambahkan pada media tumbuh. Tahap pewarnaan dilakukan pada media tumbuh selama 30 menit, dalam selang waktu ini pewarna merah kongo atau congo red akan mendeteksi zona yang mampu dihidrolisis oleh selulase. Prinsip pewarnaan ini adalah zat pewarna akan berdifusi ke dalam media agar dan hanya akan diabsorbsi oleh rantai panjang polisakarida yang memiliki ikatan $\beta$-D-Glukan (Zhang et al., 2006).

Isolat bakteri dengan kode SI-C, SI-E, SIF, SI-H, SI-L, SI-P, SIII-C adalah isolat bakteri yang bereaksi positif, ditandai dengan perubahan warna pada media tumbuh yang semula berwarna merah setelah ditetesi pewarna merah kongo atau congo red akan berubah menjadi bening atau tidak berwarna, selain itu ditandai juga dengan terbentuknya zona pada media tumbuh. Zona bening yang terbentuk memiliki ukuran diameter yang berbeda-beda antara isolat yang satu dengan isolat yang lain, dimana isolat bakteri dengan kode SI-E yang memiliki nilai indeks selulotik terbesar yaitu $4.7 \mathrm{~mm}$ sedangkan isolat bakteri bakteri dengan kode SI-F memiliki nilai indeks selulotik terkecil.

Perbedaan ukuran zona bening yang dihasilkan oleh ketujuh isolat bakteri berhubungan erat dengan kemampuan masingmasing isolat bakteri dalam menghasilkan enzim selulase. Isolat bakteri yang memiliki aktivitas enzim selulase yang tinggi dapat menghidrolisis 
selulosa menjadi glukosa sehingga mampu menunjukkan zona bening yang berukuran besar di sekitar koloni pada media tumbuhnya.

Hasil produksi enzim dapat diketahui melalui nilai aktivitas enzim yang dihasilkan oleh ketujuh isolat bakteri yang diuji. Berdasarkan hasil penelitian isolat bakteri dengan kode SI-H memiliki nilai aktivitas tertinggi yaitu 0,071 $\mathrm{U} / \mathrm{mL}$ dan aktivitas terendah dimiliki oleh isolat bakteri dengan kode SI-E yaitu 0,004 U/mL. Perbedaan nilai aktivitas yang dimiliki oleh isolate bakteri dipengaruhi oleh gen dari masingmasing isolat dan sumber karbon yang digunakan (Meryandini et al., 2009).

Selulosa yang digunakan dalam penelitian ini adalah substrat selulosa komersil yaitu karboksimetil selulos (CMC) cair dengan konsentrasi 1\%. CMC merupakan substrat yang dipakai untuk menginduksi sintesis enzim selulotik ekstraseluler (Alam et al. 2004) dan konsentrasi $1 \%$ merupakan konsentrasi yang optimum untuk produksi selulase. CMC juga merupakan jenis selulosa murni yang berbentuk amorphous dan hanya dapat dihidrolisis menggunakan enzim selulase jenis endo-1,4- $\beta$ glukanase. Hal tersebut berarti isolat bakteri SI$\mathrm{H}$ merupakan isolat yang menghasilkan enzim selulase jenis endo-1,4- $\beta$-glukanase terbanyak sehingga memiliki nilai aktivitas enzim yang tinggi dibandingkan dengan isolat yang lainnya.

Hasil uji kualitatif isolat bakteri SI-H merupakan isolat yang mempunyai indeks selulotik terbesar ketiga setelah isolat bakteri SIE, sedangkan uji kuantitatif isolate SI-E memiliki nilai aktivitas terendah dibandingkan isolat bakteri SI-H. Seleksi mikroba secara kuantitatif merupakan suatu konfirmasi dan hasilnya belum tentu tepat dengan hasil yang diperoleh pada saat uji kualitatif, hal ini disebabkan oleh kondisi lingkungan mikro yang berbeda antara medium padat dan kultur terendam atau medium cair saat pengujian sehingga mempengaruhi produksi enzim (Purwadaria et al., 2013). Isolat SI-H yang berdasarkan hasil kuantitatif memiliki nilai aktivitas tertinggi sedangkan secara kualitatif tidak memungkinkan bahwa isolate bakteri SI-H merupakan mikroba yang memerlukan kadar oksigen yang tinggi untuk pertumbuhannya, sehingga ketika ditumbuhkan pada media padat CMC $1 \%$ isolat bakteri $\mathrm{SI}-\mathrm{H}$ menghasilkan enzim yang sedikit ditandai dengan ukuran zona bening yang terbentuk pada media tumbuhnya.

\section{SIMPULAN}

Secara kuantitatif diperoleh tujuh isolat bakteri yang mampu membentuk zona bening dengan nilai indeks selulotik yang berbeda. Nilai indeks selulotik terbesar dimiliki oleh isolat bakteri SI-E yaitu $4.7 \mathrm{~mm}$ dan nilai indeks terkecil dimiliki oleh isolat bakteri SI-F yaitu $1.1 \mathrm{~mm}$. Berdasarkan uji kuantitatif isolat bakteri SI-H menghasilkan aktivitas enzim selulase tertinggi yaitu $0.071 \mathrm{U} / \mathrm{mL}$ sedangkan aktivitas enzim selulase terendah yaitu 0.004 $\mathrm{U} / \mathrm{mL}$ dihasilkan oleh isolat bakteri SI-E.

\section{DAFTAR PUSTAKA}

Alam, M, M. Manchur., M. Anwar. 2004. Isolation, purification, characterization of cellulolytic enzymes produced by the isolate Streptomyces omiyaencis. Pak J. Biol Sci. 7(10): 1647-1643.

Hamel, J.W., H. Abubakar., S. Ratnawati. 2016. Skrining Isolat Bakteri Penghasil Enzim Hidrolisis (Amilase, Lipase, Protease, dan Selulase) Dari Sedimen Ekosistem Lamun di Perairan Rendani Manokwari. Prosiding Seminar Nasional: Biodiversitas, Sains dan Matematika. Hal 138-144.

Hartanti. 2010. Isolasi dan Seleksi Bakteri Selulotik Termofilik dari Kawah Air Panas Gunung Panccar, Bogor. Skripsi FMIPA IPB Bogor.

Imas, T. 2009. Microbiology Essensial. Jakarta.

Kim, K.H., J.S. Ham, C.B. Yang., I.B. Chung; M.K. Kim; K,N. Kim. 2004. Isolation and characterization $\mathrm{pH}$ cellulose screting bacterium from cattlemanure: Application to composting. Compost Science \& Utilization, 12:242-248.

Lee.Y.2008. Purification and characterization of cellulose produced by Bacillus amyoliquefaciens DL-3 utilizing rice hull. Bioresource Technology 99:378-386.

Marks, D. B. A. D., C.M. Marks., Smith. 2000. Biokimia Kedokteran Dasar: Sebuah Pendekatan Klinis. Penerbit Buku Kedokteran EGC. Jakarta

Meryandini, A.W. Widosari., B. Maranatha, T. C. Sunarti, N. Rahmania., H. Satria. 2009. Isolasi Bakteri Selulotik dan Karakteristik Enzimnya. Makara Sains, 13:33-38. 
Mosier, N.C. Wyman. 20015. Featues of Promising Techno logies for Pretreatment of Lignocellulosic Biomass. Bioresource Technology,96(6)673-686

Narasimha, G. 2005. Nutrient effects on productions of cellulolytic enzymes by Aspergillus niger. Journal Biothecnol 5:472-476

Purwadaria, T., P. Marbun., Arnold., P. Kentaren. 2003. Perbandingan aktivitas enzim selulase dari bakteri dan kapang hasil isolasi dari rayap. JITV. 8: 4.
Suhartono, M. T. 1989. Enzime Bioteknologi. Direktorat Jenderal Pendidikan Tinggi Antar Universitas Bioteknologi. IPB

Sumardjo, Damin. 2009. Buku PanduanKuliah Mahasiswa Kedokteran dan Program Strata I Fakultas Bioeksakta. Jakarta: EGC.

Zahidah, D. S. Maya. 2013. Isolasi, Karakterisasi dan Potensi Bakteri Aerob sebagai Pendegradasi Limbah Organik. Jurnal Sains dan semi Pomits. 2(1)

Zhang, Y., M.E. Himmel., J.R. Miellenz. 2006. Outlook for cellulase improvement screening and selection strategies. Biothecnol Adv. 24:452- 454. 